\title{
Sınıf Öğretmenleri Hayat Bilgisi Derslerinde Örnek Olay Yazıyor: Bir Öğretmen Eğitimi Süreci ${ }^{1}$
}

\author{
Dr. Nur ÜTKÜR* \\ İstanbul Üniversitesi, Hasan Ali Yücel Eğitim Fakültesi, Beyazıt / İstanbul / Türkiye, \\ nur.utkur@istanbul.edu.tr, ORCID: 0000-0003-2062-5430 \\ Prof. Dr. Yücel KABAPINAR \\ Marmara Üniversitesi, Atatürk Eğitim Fakültesi, Göztepe, Kadıköy / İstanbul / Türkiye, \\ ykabapinar@marmara.edu.tr, ORCID: 0000-0001-6039-0096
}

\section{$\ddot{O} z$}

Örnek olay incelemesi yöntemi Hayat Bilgisi derslerinde kullanılmakta olan aktif öğrenme yöntemlerinden biridir. Bu yöntemin Hayat Bilgisi derslerinde nitelikli kullanımı önem taşımaktadır. Araştırmanın genel amacı, öğretmenlerin Hayat Bilgisi derslerinde örnek olay incelemesi yöntemini ne derece etkin kullandıklarını saptamak ve öğretmenlere verilen eğitimin ardından yöntemin sınıf içinde kullanımı sonrasındaki değişimi ortaya koymaktır. Bu genel amaç doğrultusunda bu çalışmada verilen eğitim öncesi ve sonrasında öğretmenlerin kullandıkları örnek olay metinlerinin niteliğine yönelik görüşlerinin alınması ve kendilerinin oluşturdukları metinlerin incelenmesi amaçlanmıştır. İstanbul ili Anadolu yakasından seçilen sosyo-ekonomik

\footnotetext{
${ }^{1}$ Bu çalışma Marmara Üniversitesi, Eğitim Bilimleri Enstitüsü, Sınıf Öğretmenliği Anabilim Dalı’nda, Nur ÜTKÜR tarafından Yücel KABAPINAR danıșmanlığında hazırlanan "Örnek Olay Yönteminin Hayat Bilgisi Dersinde Uygulanmasına Yönelik Bir Eylem Araştırması" başlıklı doktora tezinin bir bölümüdür.

* Sorumlu Yazar. Tel: +90 5309624808

(C) 2018 Kalem Eğitim ve Sağlık Hizmetleri Vakfı. Bütün Hakları Saklıdır. ～ISSN: 2146-5606
} 


\title{
Dr. Nur ÜTKÜR / Prof. Dr. Yücel KABAPINAR
}

düzeyi yüksek olan bir özel okul ve sosyo-ekonomik düzeyi düşük olan bir devlet ilkokulunda eğitim veren 7 sınıf öğretmeni çalışma grubunu oluşturmaktadır. Çalışmada veriler 2014-2015 eğitim öğretim yılında toplanmıştır. Çalışma nitel araştırma yöntemlerinden eylem araştırması niteliğini taşımaktadır. Veri toplama araçları olarak açık uçlu anket, görüşme ve doküman inceleme kullanılmıştır. Veriler içerik analizi yöntemiyle analiz edilmiştir. Araştırmanın sonuçlarına göre öğretmenler genel olarak, verilen eğitimden önce kullandıkları örnek olayların yaşantılara dayalı, düşünsel, empatik ve ahlâkî soru sormaya yönelik olmadığını düşünmektedirler. Verilen eğitim sürecinde ise öğretmenler, örnek olay yazma ve bunları derslerinde kullanma sürecinden mutlu olduklarını ve bu süreci beğendiklerini ifade etmiş̧lerdir. Ayrıca yapılan doküman inceleme sonucunda, öğretmenlerin yazdıkları örnek olay metinlerinin özelliklerinin nitelikli örnek olay özelliklerine uyduğu tespit edilmiştir.

Anahtar Kelimeler: Örnek olay yöntemi; Sınıf öğretmenleri; Hayat bilgisi dersi; Eylem araştırması.

\section{Elementary School Teachers Writing Case Studies In Life Studies Course: A Teacher Training Process}

\begin{abstract}
The case study method is one of the active learning methods used in Life Studies courses. Using this method effectively in Life Studies courses is crucial. The overall aim of this research is to determine how effectively teachers use the method of case study in their Life Studies courses, to put the change in the use of the method within the classroom following the education given to the teachers out. The purpose of this study is to get the opinions of the teachers about the nature of the sample event texts used before and after the training and to examine the texts they created. These working group have been consist of a private school with a high socio-economic level selected from the Anatolian side of İstanbul and a 7 class teacher who teaches in a state primary school with a low socioeconomic level. Data has been collected in 2014-2015 educational year. The study has been carrying the nature of action research of qualitative research methods. As data collection tools, data were collected using open-ended pre-cue and final perception questionnaire, teacher logs and document review. According to the results of the research, teachers think that the case studies they used prior to the education given are not based on experience, that the events
\end{abstract}


are not thought-provoking, and they are not directed at asking empathic and moral questions. Teachers have expressed that they are happy with the case writing process and using them in their lessons that they like this process in the training process. Also, as a result of the document review, the characteristics of the sample event texts written by the teachers have been determined. Teachers stated that they have improved themselves and the students after the training, and that this training is very useful.

Keywords: Case study method; Elementary school teachers; Life studies course; Action research.

\section{Extended Summary}

\section{Purpose}

Among the teaching methods that can be used in the classroom environment, one of the important methods to take place in the courses of Life Studies is "Case Study". Case study-based training, especially because of the detailed handling of an event, ensures that students are intertwined with elements from everyday life. In this context, the students will have the chance to play a role in different characters with the activities that are going on and they will be able to experience real life in this respect. After the appropriate learning environment is established for the implementation of the case study method, it is necessary to pay attention to the characteristics of the case studies brought against the students. In the courses related to social sciences it can be seen that only a very small part of the events and situations that can be encountered in life can be carried into the classroom. It has been found that due to various reasons in the classroom environment, the case method can't be used effectively enough and in this context. It can't be done adequately enough to relate the students' real life. It is also stated that while the case studies in the Life Studies textbooks are meant to force students to be compelling and contentious, it should be noted that the case studies chosen by the teacher are relevant to their life and their relevance to their life.

It is an undeniable fact that teachers have a great duty and responsibility in this regard. It is important for the teachers to be aware of this issue so that the case method can be used qualitatively in the classroom environment. The overall aim of this research is to determine how effectively teachers use the method of case study in their Life Studies courses, to put the change in the use of the method within the classroom following the education given to the teachers out. In line with this general objective, the purpose of this study is to 


\section{Dr. Nur ÜTKÜR / Prof. Dr. Yücel KABAPINAR}

get the opinions of the teachers about the nature of the sample event texts used before and after the training and to examine the texts they created. For this purpose, it has been searched for answers to the following research questions.

1. What are the opinions of the teachers for the effective use of case studies in the Life Studies courses before and after the training given to the teachers?

2. How is the nature of the sample event texts created by teachers for use in the after the training given to the teachers Life Studies courses?

3. What are the opinions of the teachers regarding the classroom environment before and after the education given to the teachers?

\section{Method}

In this study, action research was used qualitative research designs. The action research has been seen as the last category in the theory-action plane, and a program aims to solve specific problems in an organization or community. Action researches make people part of the change process openly and purposefully by including them in programs and organizations to solve their problems. In the study year 2014-2015, working group has been consisted of a private school with a high socio-economic level selected from the Anatolian side of İstanbul and 7 class teachers who teaches in a state primary school with a low socioeconomic level. Teachers have been selected on the basis of volunteerism, with 2 out of the $2^{\text {nd }}$ grade and 2 out of the $3^{\text {nd }}$ grade in both private and public schools. As data collection tools in work, data were collected using open-ended pre-cue and final perception questionnaire, teacher logs and document review.

\section{Results, Discussion, Conclusion}

In order to be able to determine what the opinions of the teachers about the case studies are given before and after the given case study based training, the kept teacher logs have been analyzed. All-round thoughts have in the diaries of the teachers who started to keep their diaries after the given training. It is seen that the views of the teachers about the case studies in the pre-training textbooks and the course processing using them are examined in two different main themes. The first of these is "incompetence" and the second is "lessons structured". Teachers have been identified as the opinions expressed on the theme of "insufficiency of events" are examined; 2 of the teachers said that the events were "not based on experience", 2 of the teachers 
said that the events were "not thought-provoking" and that one was "not aimed at asking empathic and moral questions".

Following the case study based on the given case study, it was required that the teachers prepare 4 of the sample case texts for the 6 courses that the teachers would process using the case study and the last 2 would be prepared by the teachers working in pairs. The opinions obtained from the teacher's diaries were analyzed in two main themes as "positive points" and "difficulty points". When examining the sub-themes of the teachers' positive points; while writing sample texts, 5 of the teachers liked "to be supported by feedbacks", 4 "can easily do person and event fiction", and " 2 of them are inspired by events", 2 of them are "benefiting from previous case events ' 2 of them' use educational materials "and 1 in the sample event texts" have been asked to transfer to other courses has been identified.

It is required to work with 2 persons in line with the issues and achievements given in after the training given by the teachers to create sample event texts. The 4 teachers in the private school work with 2 persons and put up 1 sample event text for each group; each of the 3 teachers in the state school has individually created case studies. After the feedback from the researcher has been taken and the necessary corrections have been made, the total number of sample case texts the teachers put out is 10 . All of the sample case texts, created by the teachers, were identified as "the fact that he possessed real-life features, enabled empathy with the characters, and provided information on character, location, event". Among the revealed texts, 9 "contains situations of conflict, including thinking and debating"; 8, it is determined that "the result is not clear". It has been determined that half of the sample cases presented by the teachers can meet the "being a brief" criteria.

It was determined that there were a total of 29 opinions on the sub-themes related to the development of the as a result of the data obtained from the open-ended questionnaire and the teacher's diary for the post-training process given to the teachers towards "themselves" and a total of 19 opinions related to their development towards "students". In the sub-themes of the teachers' "developments towards themselves", all of the teachers thought that, "intellectual, moral and empathic questions are balanced" after the education, 4 of the teachers expressed their opinions about "awareness of the possibility of creating a case" and "introduction of case method". While 3 of the teachers expressed their thoughts on "clear, clear and long-answer question" and 


\section{Dr. Nur ÜTKÜR / Prof. Dr. Yücel KABAPINAR}

"grasp of the importance of exhibiting and evaluating products", 2 of them expressed their opinions about "the event can be formed". There are only six different categories in which a teacher gave an opinion about teachers' development towards themselves. These are "The awareness of the development of creativity, the awareness raising, the enjoyment of the Life Studies courses, the connection between the questions and the questions, the inadequacy of the sample case texts in the books and the transfer to different lessons".

\section{Giriş}

Eğitimin çağdaşlaşması sonucu hem eğiten hem de eğitilen bireyin en önemli sorunlarından biri, eğitimin nasıl ve hangi yollarla daha nitelikli hale getirilebileceği olmuştur. Bireyler gelişen ve değişen dünyanın niteliklerine uyum sağlayabilmek için her açıdan kendilerini geliştirmek durumunda kalmıştır. Bu nedenle okullarda işlenen derslerin niteliklerinin de bahsedilen boyutlarda geliştirilmesinin gerekli olduğu görülmüştür. Bu nitelikli gelişim ve değişim sayesinde karar verme becerileri üst boyutlarda olan, kararlarının neden-sonuç ilişkilerini önceden düşünerek, kendisine, ailesine ve etrafındaki insanlara, etkilerine dikkat eden, çevresindeki kişilerle empati kurabilen bireyler yetiştirmek hedeflenmektedir.

$\mathrm{Bu}$ bağlamda düşünüldüğünde ilkokullarda okutulan Hayat Bilgisi dersi ayrı bir öneme sahiptir. Çünkü bu derste gerek yaşam öyküleri işlenip, gerekse de birbirinden farklı disiplinleri ele alan bir yapı yer almaktadır (Millî Eğitim Bakanlığ bulabilmeleri göz önüne alındığında, dersin bahsedilen değişim ve gelişimleri öğrencilere kazandırabilme konusunda önemli bir yapısının olduğu düşünülmektedir.

Öğrencilerin öğretilenleri somut olarak anlamlandırabilmeleri açısından ele alınması gereken diğer bir önemli konu ise, öğrenme ortamında kullanılacak öğretim yöntemlerinin niteliğidir. Bu konuda yapılan çalışmalar (Morris, 2001; Rosler, 2008; Schroeder, Scott, Tolson, Huang ve Lee, 2007; Ütkür, 2016) incelendiğinde, farklı öğretim yöntemlerinin sınıfta kullanılmasının birbirinden farklı olumlu sonuçlara hizmet ettiği tespit edilmiştir.

Farklı öğretim yöntemlerinin sınıf ortamında aktifliği arttırdığı göz önüne alındığında, öğretmenlerin bunları nitelikli kullanmaları önem taş1maktadır. Bu öğretim yöntemlerinden Hayat Bilgisi derslerinde sıklıkla kullanılanlar arasında örnek olay da yer almaktadır. Yapılandırmacı yaklaşım 
temelli 2004 yılında Millî Eğitim Bakanlığı tarafından pilot olarak uygulamaya konulan Hayat Bilgisi Öğretim Programı çerçevesinde en aktif hâle gelen öğretim yöntemlerinden biri de örnek olay olmuştur (Kabapınar, 2012). Örnek olay temelli eğitim, özellikle bir olayın ayrıntılı olarak ele alınması sayesinde, öğrencilerin günlük hayattan unsurlarla iç içe olmalarını sağlamaktadır. $\mathrm{Bu}$ bağlamda örnek olayın devamında gelen etkinliklerle öğrenciler birbirinden farklı karakterlere bürünebilmekte ve bu sayede gerçek hayattan unsurlarla karşı karşıya gelebilmektedirler (Farahani ve Heidari, 2013). Örnek olayın sağladığı yararlardan bir diğeri de, bireylerin problemlerin çözümüne karşı farklı bakış açılarını geliştirme fırsatıdır. Aynı zamanda teori ve pratik arasında bağlantı noktaları oluşturmalarına yardımcı olmaktır. Ayrıca örnek olay yöntemi, bireylerin problem çözme ve eleştirel düşünme becerilerini de geliştirebilmektedir (Badger, 2010).

Hayat Bilgisi dersleri de çocuğun gerçek hayatında karşılaştığı problemlere çözümler bulabilmesi ve kendisini rahatça ifade edebilmesini sağlayan bir ders olduğundan, bu derslerde örnek olay yönteminin kullanılması önem taşımaktadır. Örnek olay, "Bir olayın ya da sorunun yazılı veya sözlü şekilde anlatıldıktan sonra konu hakkında öğrencilerin tartıştırılmasıyla çözüm ve önerinin ortaya konmasına dayanan bir yöntemdir." (Aydın, 2011, s.85). Ayrıca Kabapınar ve Baysal'a (2004) göre, öğrencilerin derslerde aktif olabilmeleri ve bireysel anlamlar çıkarabilmeleri, öğrenmenin kalıcılığı açısından örnek olay, üzerinde durulması gereken bir konu olmaktadır. $\mathrm{Bu}$ amaçla farklı bakış açılarının ortaya konulması ve farklı fikirlerin tartışılmasına zemin hazırlanması açısından örnek olay yönteminin Hayat Bilgisi derslerinde kullanılması önemlidir.

Örnek olay yönteminin uygulanmasında uygun öğrenme ortamı hazırlandıktan sonra, öğrencilerin karşısına getirilen örnek olayların özelliklerine dikkat etmek gerekmektedir. Sosyal bilimlerle ilintili derslerde yaşam içerisinde karşılaşılabilecek olay ve durumların ancak çok küçük bir bölümünün sınıf içine taşınabildiği görülmektedir. Sınıf ortamındaki çeşitli gerekçelerden ötürü örnek olay yönteminin yeterince etkili biçimde kullanılamadığ1 ve bu bağlamda öğrencilerin gerçek yaşamıyla ilişkilendirmelerin yeterli ölçüde yapılamadığı tespit edilmiştir (Kabapınar, 2012; Özkan, 2010). Sınıfların kalabalık olması ve uzun zaman alan örnek olaylarda bütünlük sağlanamaması, öğrencinin olay ve ilişkiler arasında kolay bir bağ kuramamasına neden olmaktadır. Öte yandan Kabapınar (2009) Hayat Bilgisi ders 
kitaplarındaki örnek olayların öğrencileri zorlayan ve çatışma içerikli nitelikte olması gerektiğini belirtirken; Özkan (2010) çalışmasında öğretmenin seçtiği örnek olayların öğrencilerin yaşamlarıyla bağlantılı ve seviyelerine uygun olmasına dikkat edilmesi gerektiğini ifade etmiştir.

$\mathrm{Bu}$ konuda öğretmenlere büyük görev ve sorumluluk düşmektedir. Örnek olay yönteminin sınıf ortamında nitelikli kullanılabilmesi için öğretmenlerin bu konuda bilinçlendirilmesi önem taşımaktadır. Bu bilinçlendirilmeyi hayata geçirmek için bu araştırmada, öğretmenlerin Hayat Bilgisi derslerinde örnek olay incelemesi yöntemini ne derece etkin kullandıklarını saptamak, öğretmenlere verilen eğitimin ardından yöntemin sınıf içinde kullanımında ortaya çıkan değişimi ortaya koymak amaçlanmıştır. Bu genel amaç doğrultusunda bu çalışmada verilen eğitim öncesi ve sonrasında öğretmenlerin kullandıkları örnek olay metinlerinin niteliğine yönelik görüşlerinin alınması ve kendilerinin oluşturdukları metinlerin incelenmesi amaçlanmıştır. Bu amaçla aşağıdaki araştırma sorularına cevap aranmıştır-

1. Öğretmenlere verilen eğitim öncesi ve sonrasında Hayat Bilgisi derslerinde işlenen örnek olayların etkili kullanımına yönelik öğretmen görüşleri nelerdir?

2. Öğretmenlere verilen eğitim sonrasında Hayat Bilgisi derslerinde kullanılmak üzere öğretmenler tarafından oluşturulan örnek olay metinlerinin niteliği nasıldır?

3. Öğretmenlere verilen eğitim öncesi ve sonrasındaki sınıf ortamına ilişkin öğretmen görüşleri nelerdir?

\section{Yöntem}

\section{Araştırmanın Deseni}

$\mathrm{Bu}$ araştırmada nitel araştırma desenlerinden eylem araştırması kullanılmıştır. Eylem araştırması teori-eylem düzlemindeki son kategori olarak görülmektedir ve bir program, örgüt ya da topluluktaki özel problemleri çözmeyi amaçlamaktadır. Eylem araştırmaları kendi problemlerini çözmeleri için insanları program ve örgütlere dahil ederek açık ve amaçlı bir şekilde değişim sürecinin bir parçası hâline getirmektedir (Whyte, 1989'dan akt; Patton, 2014, s.221). Eylem araştırmaları planlama, eyleme dönüştürme, gözlem yapma ve yansıtma basamaklarından oluşan bitmeyen bir süreci içermektedir. $\mathrm{Bu}$ süreç sayesinde de elde edilen sonuçlar ışı̆̆ında eylem gözden geçirilerek uygulamaya konulmaktadır (Levin, 1946'den akt; McNiff 
ve Whitehead, 2002, s.40).

$\mathrm{Bu}$ çalışmada eylem araştırması kullanılmasının nedeni ise, çalışmanın doğasına en uygun nitel araştırma yöntemi olmasıdır. Var olan bir problemin tespiti (Özkan, 2010) sonrasında, bir eğitim programı geliştirilerek bu problemi çözmeye yönelik çalışmalar eylem çemberindeki basamaklar doğrultusunda şekillendirilmiştir.

\section{Çalışma Grubu}

Araştırmada 2014-2015 eğitim-öğretim y1lında İstanbul ili Anadolu yakasından seçilen sosyo-ekonomik düzeyi yüksek olan bir özel okul ve sosyo-ekonomik düzeyi düşük olan bir devlet ilkokulunda eğitim veren 8 sinıf öğretmeni çalışma grubunu oluşturmaktadır. Öğretmenler, özel okul ve devlet okulunun her ikisinde de 2. sinıftan 2'şer ve 3. sinıftan 2'şer olmak üzere gönüllülük esasına uygun olarak seçilmiştir.

Ön gözlemler (her öğretmenin 6'şar ders saatinin izlenmesi) yapıldıktan sonra, devlet okulunda görev yapmakta olan 2. sınıf öğretmenlerinden biri okuldan ayrılmak zorunda kaldığı için öğretmen sayısı 7'ye düşmüştür. Böylece öğretmenlere verilen eğitime ve son gözlemlere toplam 7 öğretmenle devam edilmiştir. Öğretmenlerin hepsinin cinsiyeti kadındır. Çalışmada öğretmenlerin isimlerine yer verilmeyerek, özel okul öğretmenleri ÖÖ1, ÖÖ2 şeklinde ve devlet okulu öğretmenleri DÖ1, DÖ2 şeklinde kodlanmıştır.

Araştırmada öğretmen örneklemi belirlenirken amaçlı örnekleme yöntemlerinden ölçüt örneklem kullanılmıştır. Ölçüt örneklemede, daha önceden belirlenmiş bazı ölçütlere göre örneklem seçilmektedir. Seçilen durumların ise bilgi verme açısından zengin olması önem taşımaktadır (Patton, 2014). Öğretmenleri seçerken özel okul ve devlet okullarının müdürleriyle görüşülmüş ve çalışmalara katılım açısından istekli olan öğretmenlerin belirlenmesi önemli bir ölçüt olmuştur. Güz ve bahar dönemi olarak eğitim-öğretim yılının tamamında çalışmalara katılmaya istekli olan 2. ve 3. sınıf öğretmenleri belirlenmiştir.

\section{Veri Toplama Araçları}

Açık Uçlu Ön Algı ve Son Algı Anketleri: Bu çalışmada anket geliştirme süreci dikkate alınarak, öğretmenlere verilen eğitimden önce ve sürecin en sonunda uygulanan ön algı ve son algı anketleri, açık uçlu anket soruları şeklinde düzenlenmiştir. Açık uçlu ön alg1 anketinde toplam 7 soru bulunurken, son 


\section{Dr. Nur ÜTKÜR / Prof. Dr. Yücel KABAPINAR}

alg1 anketine bir soru eklenmiş olup toplamda 8 soru yer almaktadır. Hazırlanan sorularla ilgili olarak uzman görüşü alınmıştır. Uzman görüşlerinden elde edilen veriler doğrultusunda ankette yer alan soruların kapsam geçerlik indeksi (KGİ), Lawshe (1975) tekniğiyle incelenmiştir. Ön alg1 anketinde yer alan soruların KGİ'sinin 0.93 ve son alg1 anketinde yer alan soruların 0.94 olduğu ve 0.75 'ten büyük olmalarından ötürü Lawshe (1975) tekniğine göre anlamlı olduğu tespit edilmiştir (akt; Yurdugül, 2005).

Ön alg1 ve son alg1 anketinde ortak olan sorular, öğretmenlerin yap1landırmacılık/davranışçılık farkını ele alabilmelerine, örnek olay yönteminin Hayat Bilgisi derslerinde kullanmalarına yönelik algılarının neler olduğuna, ders kitaplarında yer alan örnek olay metinlerinin niteliğine ve örnek olay yönteminin öğrencilerde geliştirebileceği tutum ve becerilerin neler olduğuna yöneliktir. Son alg1 anketi formunda ise ön alg1 anketinden farklı olarak öğretmenlerden, verilen eğitim süreci ve kendilerinde gördükleri değişimlerle ilgili olarak görüşlerini yazmaları da istenmiştir.

Öğretmen Günlükleri: Günlükler öz-değerlendirme araçları olup, günlük durumlar içerisinde sosyal ve psikolojik süreçleri araştırma firsatı veren deneyimleri incelemek üzere tekrar tekrar kullanılabilmekte, böylece sürecin gelişimine dair içerik konusunda bilgi sahibi olunmasını sağlamaktadır (Bolger, Davis ve Rafaeli, 2003).

Öğretmenlerin süreçte yaşadıkları problemler ve çözüm yolları ile duygu ve düşüncelerinin araştırmacı açısından dönüt oluşturabilmesi bakımından öğretmen günlükleri kullanılmıştır. Öğretmenlerin eğitim öncesindeki ders işlemelerine herhangi bir etkinin olmasının engellenmesi için, araştırmacı tarafından neyin gözlemlendiği öğretmenlere belirtilmemiştir. $\mathrm{Bu}$ nedenle öğretmenler süreç hakkındaki düşüncelerini yazmak için günlükleri tutmaya eğitimin verilmesinin ardından başlamışlardır. Öğretmenlere günlükleri belirlenen amaçlar çerçevesinde tutabilmeleri amacıyla, belirli kategoriler verilmiş ve bunlar doğrultusunda sürece yönelik görüşlerini yazmaları istenmiştir.

Doküman inceleme: Çalışmada öğretmenlerin yazdıkları örnek olay metinlerinin analizi, doküman inceleme yöntemi ile yapılmıştır. Dokümanlar, gözlem ya da görüşme gibi kısmen daha uzun süren veri toplama araçlarına gerek kalmadan bilgiye ulaşmayı sağlayan ve nitel araştırmalarda özellikle kullanılması gereken kaynaklardandır (Yıldırım ve Şimşek, 2011). Bu çalışmada, verilen eğitim sonrasında öğretmenlerin hazırladıkları örnek olay metinleri 
doküman incelemesine tâbi tutulmuştur. Bunun için nitelikli bir örnek olay metninin içinde barındırması gereken özellikleri ele alan Davis'in (1993) kriterlerinden yararlanılmıştır (akt; Beckisheva, Gasparyan ve Kovalenko, 2015). Öğretmenlerin verilen eğitim sonrasında yazdıkları örnek olay metinleri incelenerek nitelik düzeyleri belirlenmeye çalışılmıştır.

\section{Veri Toplama Süreci}

$\mathrm{Bu}$ araştırmanın yapılabilmesi için gerekli izinler İl Millî Eğitim Müdürlüğü'nden alınmıştır. Ardından İstanbul ilinin Anadolu yakasındaki sosyo-ekonomik düzeyi düşük bir bölgeden bir devlet okulu ve görece daha yüksek sosyo-ekonomik düzeyli bir bölgeden özel bir okul seçilmiştir. Ardından bu özel okul ve devlet ilkokullarından 4'er kişi olmak üzere toplamda 8 sınıf öğretmeni seçilmiştir. Her iki okul için de bu öğretmenlerden ikisi 2. sınıf ve ikisi 3. sınıf öğretmenleridir. Ancak devlet okulu öğretmenlerinden birinin ön gözlemler yapıldıktan sonra okuldan ayrılması gerektiğinden, öğretmen eğitime ve dolayısıyla devamındaki süreçlere katılamamıştır. $\mathrm{Bu}$ nedenle toplamda 7 öğretmenle sürece devam edilmiştir.

Ön Gözlemler: Veri toplama sürecine öncelikle gözlemle başlanmıştır. Öğretmenlerin 2. ve 3. sınıf Hayat Bilgisi Öğretmen Kılavuzu'nda örnek olay yöntemini kullanmaları öngörülen konulardan seçilen 6'şar konuyu işlemeleri araştırmacı tarafından gözlemlenmiştir. 7 öğretmenin belirlenen 6 kazanıma ait konuyu işleme süreleri toplam 42 ders saati sürmüştür. Öğretmenler derslerin işlenmesinden önce hangi konuların işleneceğine yönelik bilgilendirilmiş ancak neyin gözlemleneceği, nelerin inceleneceği hakkında öğretmenlere herhangi bir bilgi verilmemiştir.

Uzman Görüşü Alınması: Öğretmen eğitiminin pilot uygulaması yapılmadan önce, örnek olay incelemesi temelli eğitimin içeriğine ilişkin uzman görüşü alınmıştır. $\mathrm{Bu}$ uzmanlar 6 akademisyen ve 3 sınıf öğretmeninden oluşmaktadır. Uzmanların görüşleri alındıktan sonra uygulanan Lawshe testine göre eğitimde yer alan etkinliklerin kapsam geçerlik indeks ortalamaları 0.92 olarak tespit edilmiştir.

Pilot Uygulama: Öğretmenlere verilecek olan eğitimin gidişatını görmek ve oluşabilecek sorunlara çözüm bulabilmek amaciyla öncelikle pilot uygulama yapılmıştır. Bu amaçla örnek olay incelemesi eğitimi, Sınıf Öğretmenliği Anabilim Dalı 3. sınıf öğrencilerinden 8 kişiye verilmiştir. Bu öğrencilerin 3. sınıftan seçilmesinin nedeni, çeşitli öğretim derslerini ve Okul Deneyimi 


\section{Dr. Nur ÜTKÜR / Prof. Dr. Yücel KABAPINAR}

dersini almış olmaları, ayrıca Hayat Bilgisi Öğretimi dersi kapsamında “örnek olay incelemesi" yöntemini işlememiş olmalarıdır. Pilot uygulamada öğretmen adaylarıyla, öğretmenlere verilecek eğitimdeki etkinlikler yapılmıştır. Bu etkinliklerin sonuna gelindiğinde, örnek olay ile bir dersin yapılandırılmasına yönelik olan son etkinliğin uzun sürdüğü ve öğretmen adaylarının sıkıldıkları gözlemlenmiştir. Bu nedenle belirtilen etkinliğin eğitimden çıkarılmasına karar verilmiştir. Ayrıca pilot uygulama sonucunda, öğretmen adaylarına eğitimi nasıl bulduklarına yönelik sorular sorulmuştur. Verilen cevaplara göre adayların, soru oluşturma, örnek olaya yönelik farklı etkinlikler üzerine çalışma ve birbirinden farklı öğretmenlerin dersleri üzerinde tartışma kısımlarının kendileri için yararlı olduğunu ifade ettikleri belirlenmiştir.

Öğretmen Ĕgitimi: Pilot uygulamanın ardından gerekli düzenlemeler yapılmış olan örnek olay incelemesi temelli eğitim öğretmenlere verilmiştir.

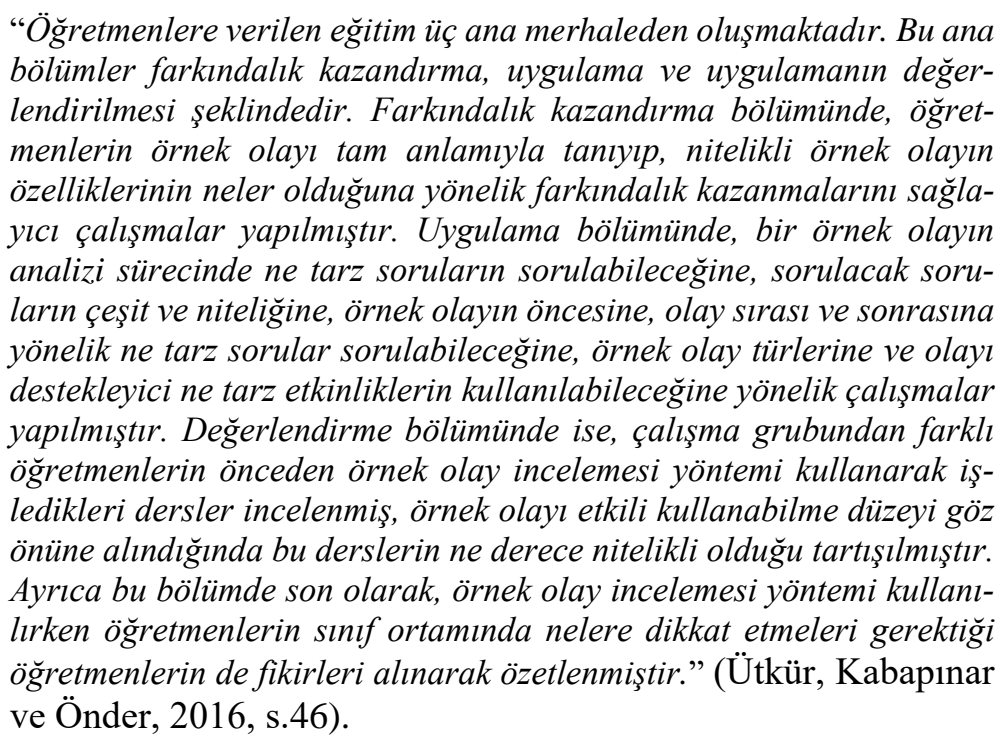

Ancak yer ve zaman sıkıntısından ötürü bu eğitim özel okul ve devlet okulu öğretmenlerine ayrı ayrı verilmiştir.

Materyallerin Hazırlanması: Verilen örnek olay incelemesi temelli eğitimin ardından, araştırmacı tarafından belirlenen 4 kazanıma uygun olarak örnek olay metinleri hazırlanmıştır. Ardından bu metinlerle ilgili olarak uzman görüşü alınmıştır. Uzmanların örnek olay metinlerinde yer alan çatışma içerikli kısımların daha net ifade edilmesi önerisi göz önüne alınarak, metinler 
bir kez daha düzenlendikten sonra öğretmenlere işleyecekleri derslerden önce dağıtılmıştır. Öğretmenlerin bu örnek olay metinlerine yönelik soracakları "düşünsel-ahlâkî-empatik" soruları ve kullanacakları etkinlikleri önceden hazırlamaları istenmiştir.

Son Gözlemler: Öğretmenlerin son gözlemlerde işledikleri 6'şar dersin araştırmacı tarafından gözlemlenmesi toplamda 42 ders saati sürmüştür. Öğretmenlerin son gözlemlerde işledikleri derslerde ilk 4 konunun örnek olay metinleri araştırmacı tarafından hazırlanmış ve uzman görüşleri alınmıştır. Ancak hangi soru tiplerinin kullanılacağı ve etkinliklerin yapılacağının planlanması öğretmenlere bırakılmıştır. $\mathrm{Bu}$ dersler öğretmenler tarafindan işlendikten ve araştırmacı tarafından gözlemlendikten sonra, öğretmenlere ders işlenişine yönelik dönüt verilmiştir. Bu dönütler her dersin işlenmesinin hemen ardından verilmiş olup, öğretmenlerin çeşitli açılardan eksik oldukları kısımlar hakkında önerilerde bulunulmuş, bir sonraki ders planının ve işlenmesinin daha nitelikli olması için öğretmenlerle birebir çalışmalar yapılmıştır. Bu derslerin bitiminden ve verilen dönütlerden sonra, son 2 derste kullanılacak örnek olayların öğretmenlerin kendileri tarafindan hazırlanması istenmiştir. Özel okul öğretmenleri örnek olay metinlerini 2'şerli çalışarak hazırlarken, devlet okulu öğretmenleri bireysel olarak hazırlamıştır. Metinlerin hazırlanmasının ardından, araştırmacı tarafından dönüt verilmiş ve gerekli düzeltmeleri yapmaları sağlanmıştır. Bu düzeltmeler, örnek olay metinlerinde çatışmanın olmasının sağlanması ve sonucun net biçimde belli olmamasına yönelik olmuştur. Örnek olay metinlerini yazan, düşünsel-ahlâkî-empatik soru tiplerini oluşturan ve örnek olayı destekleyici etkinliklerini hazırlayan öğretmenlerin bu dersleri işlemeleri araştırmacı tarafından gözlemlenmiştir.

Son Algı Anketinin Uygulanmast: Öğretmenlerin verilen eğitime ve örnek olay incelemesi yöntemi kullanarak işledikleri derslere yönelik görüşlerinin neler olduğu ve örnek olay hazırlarken karşılaştıkları güçlükleri tespit etmek amacıyla açık uçlu sorulardan oluşan son algı anketi uygulanmıştır.

Öğretmen Günlüklerinin Toplanmast: Verilen eğitim sonrasında öğretmen günlüklerinin tutulması sağlanarak, öğretmenlerin tüm sürece yönelik düşünceleri alınmış ve ayrıntılar gözden kaçırılmamaya çalışılmıştır. Öğretmenler günlüklerinde önceden belirlenen kategorilere göre eğitim öncesi, eğitim sırası ve sonrasına yönelik düşüncelerini ifade etmiştir. Öğretmenlerin derslerinin son gözlemleri bittikten sonra bu günlükler analiz edilmek üzere toplanmıştır. 


\section{Verilerin Analizi}

Açık Uçlu Ön Algı ve Son Algı Anketlerinin Analizi: Öğretmenlere uygulanan açık uçlu ön alg1 ve son algı anket formu analiz edilirken, anketteki sorulardan elde edilen verilerin analizinde içerik analizi yöntemi kullanılmıştır. Kodlardan, kategorilere ve temalara ulaşılmış, ardından sayısallaştırılarak araştırma sorularına göre tablolar oluşturulmuştur. Öğretmenlerin kimliklerinin belli olmamas1 için devlet okulu öğretmenleri DÖ1, DÖ2 şeklinde kodlanırken; özel okul öğretmenleri ÖÖ1, ÖÖ2 şeklinde kodlanmıştır. Yapılan analizlerin güvenirliğini sağlamak amacıyla Sınıf Öğretmenliği Anabilim Dalı'nda doktora yapmakta olan bir öğretim elemanı ikinci kodlayıcı olarak belirlenmiştir. 2 araştırmacının kodlamaları arasındaki tutarlılık katsayısı ön alg1 anketinde 0.93 iken, son algı anketinde 0.91 olarak hesaplanmıştır. Ayrıca veriler yorumlanırken öğretmenlerin görüşlerinden doğrudan alıntılara yer verilerek güvenirlik arttırılmaya çalışılmıştır.

Öğretmen Günlüklerinin Analizi: Öğretmen günlükleri dağıtılmadan önce araştırmacılar tarafından belli kategoriler oluşturulmuş, böylece öğretmenlerin günlükleri tutarken daha rahat olmaları sağlanmaya ça1ışılmıştır. Belirlenen kategoriler aşağıdaki şekildedir:

- Öğretmenlerin eğitim öncesi ve sonrasında kullandıkları örnek olayın nitelikleri,

- Öğretmenlerin eğitim öncesi ve sonrasında kullandıkları soru tipleri,

- Öğretmenlerin eğitim öncesi ve sonrasında kullandıkları etkinlikler,

- Eğitim süreci, örnek olay oluşturma süreci ve ders işleme planlarına yönelik düşünceler,

- Eğitim sonrasında önceye göre kendilerinde gördükleri farklılıklar,

- Öğretmenlerin eğitim öncesi ve sonrasında öğrencilerden aldıkları cevaplarda gördükleri farklılıklar.

Veriler analiz edilirken araştırmacı tarafından dikkatle okunmuş, kodlardan alt ve ana kategorilere, temalara ulaşılarak sayısallaştırılan veriler tablo haline getirilmiştir. Ayrıca öğretmenlerin yazdıklarından birebir alıntılara yer verilerek elde edilen bulgular desteklenmiştir. Veriler ikinci araştırmacı tarafından da kodlanmış olup, iki araştırmacının kodlayıcı tutarlılık değeri 0.94 bulunmuştur. 
Örnek Olay Metinlerinin Analizi: Öğretmenlerin eğitim sonrasındaki ders işleme süreçlerinde oluşturdukları örnek olay metinlerinin niteliğinin tespit edilebilmesi için, araştırmacı tarafından doküman analizi yöntemi ile metinler analiz edilmiştir. Bu metinlerin analizinde, nitelikli örnek olayın özellikleri (Davis, 1993) esas alınmıştır (akt; Beckisheva, Gasparyan ve Kovalenko, 2015). Bu kategoriler, "Gerçek hayattan alınmış özellikler taşıması; Karakterlerle empati kurulabilmesi; Karakter, yer ve olay hakkında bilgi vermesi; Düşünme ve tartışmayı içermesi; Çatışma içeren durumlar barındırması; Sonucun net olarak belli olmaması ve Kısa ve öz olması" şeklindedir. Belirlenen kategoriler çerçevesinde kod, kategori ve temalar oluşturularak analiz edilen veriler sayısallaştırılarak tablo haline getirilmiştir. Veriler ikinci araştırmacı tarafından tekrar kodlanmış ve kodlayıcı tutarlılık değeri 0.90 olarak tespit edilmiştir.

\section{Bulgular}

\section{Eŭitim Öncesi Ve Sonrasında Hayat Bilgisi Derslerinde İşlenen Örnek Olayların Etkili Kullanımına Yönelik Görüşler}

Verilen örnek olay incelemesi temelli eğitim öncesi ve sonrasında öğretmenlerin kullandıkları örnek olaylara yönelik görüşlerinin neler olduğunun tespit edilebilmesi için, tutulan öğretmen günlükleri analiz edilmiştir.

Tablo 1. Verilen Eğitim Öncesinde Kullanılan Örnek Olaylara Yönelik Öğretmen Görüşleri

\begin{tabular}{|c|c|c|}
\hline Ana Temalar & Alt Temalar & Sayı (f) \\
\hline Olayların & Yaşantılara Dayalı Olmaması & 2 \\
\hline Yetersiz & Düşündürücü Olmaması & 2 \\
\hline \multirow[t]{2}{*}{ Olması } & Empatik ve Ahlâkî Soru Sormaya Yönelik Olmaması & 1 \\
\hline & Ara Toplam & 5 \\
\hline & Canlandırma Yaptırılması & 3 \\
\hline Derslerde & Soru-cevap Yönteminin Kullanılması & 2 \\
\hline \multirow[t]{3}{*}{ Yapılanlar } & Başına Gelen Benzer Olaylardan Yararlanılması & 2 \\
\hline & Ara Toplam & 7 \\
\hline & Genel Toplam & 12 \\
\hline
\end{tabular}

Verilen eğitim sonrasında günlüklerini tutmaya başlayan öğretmenlerin günlüklerinde tüm süreçle ilgili düşünceleri yer almaktadır. Öğretmenlerin eğitim öncesindeki derslerde kullandıkları örnek olaylara yönelik görüşlerine Tablo 1'de yer verilmiştir.

Öğretmenlerin eğitim öncesi ders kitaplarında bulunan örnek olaylara ve bunları kullanarak ders işleme süreçlerine ilişkin görüşlerinin 2 farklı ana 
temada incelendiği görülmektedir. Bunlardan birincisi "olayların yetersiz olması" ve ikincisi ise "derslerde yapılanlar" şeklindedir. Öğretmenlerin "olayların yetersiz olması" temasına yönelik belirttikleri görüşler incelendiğinde; öğretmenlerden 2'sinin olayların "yaşantılara dayalı olmadığını", yine öğretmenlerden 2'sinin olayların "düşündürücü olmadığını" ve birinin “empatik ve ahlâkî soru sormaya yönelik olmaması" şeklinde düşündüğü belirlenmiştir.

Öğretmenler eğitim öncesinde kullandıkları örnek olayların yetersiz olduğunu düşünmektedir. Bunun nedeni olarak ise öğretmenlerin 2'si "yaşantılara dayalı olmamasını” göstermiştir. Konuyla ilgili görüş belirten özel okul öğretmenlerinden ÖÖ3'ün görüşleri şu şekildedir:

\begin{tabular}{|c|}
\hline * Egitim öncesinde örnek olaylar ders \\
\hline Kitabindan yararlanarak kullanyordum. Des \\
\hline kitabinaki sayfalare PDF seltinde tahtaya \\
\hline yansitarak görsel ve dialoglardan gararlandem \\
\hline Buradaki oirnek olaylar genelde okol hayatin. \\
\hline konu alyordu. Önekler cok klasikti.Farkl. ve \\
\hline Garpia bulmadim bu yüzden Günlül yasamdas \\
\hline
\end{tabular}

Öğretmen verilen eğitim öncesinde ders kitaplarında yer alan örnek olayları kullandığını, ancak örneklerin klasik olmasından ötürü farklı ve çarpıcı olmadığını ifade etmiştir. ÖÖ3'ün görüşlerine göre, Hayat Bilgisi derslerinde kullandığı örnek olaylara günlük hayattan farklı konular eklemek istediği belirlenmiştir. Özel okul öğretmenlerinden ÖÖ4, eğitim öncesinde kullandığı örnek olayların "düşündürücü olmadığını” ifade ederek görüşlerini günlüğünde şu şekilde belirtmiştir: 


- Ders kitaplarinda fazla önek olayimizin
olmayișl egitim acisindan yetersiz buluys-
rum. Olan örnek olaylar sinifta okutu-
lup ögrenciler tarafindan sinif icinde
dramalastirarak görsellerini inceleyerek
sinifta paylastim. Örnek olaylari cok
basit. Daha dusundiricu ve cözüm bul-
durucu depit.

ÖÖ4'ün görüşlerine göre, ders kitaplarında fazla örnek olay bulunmamakta, olanlar ise görece basit kalmaktadır. Öğretmen, ders kitaplarında yer alan ve verilen eğitim öncesi kullandığı örnek olayların düşündürücü ve çözüm bulmaya yönelik olmadığını ifade etmektedir. Öğretmenlerin verilen eğitim öncesinde kullandıkları örnek olayları ders ortamında nasıl kullandıklarına yönelik görüşleri "derslerde yapılanlar" temasında toplanmıştır. Öğretmenlerden 3'ü örnek olayları işlerken “canlandırma yaptırdığını”, 2'si "soru-cevap yöntemini kullandığını" ve yine 2'si "başından geçen benzer olaylardan yararlandığını" ifade etmiştir. Verilen eğitim öncesinde derslerinde örnek olayı işlerken "canlandırma yaptırdığını” belirten devlet okulu öğretmenlerinden DÖ2, bu konudaki görüşlerini şu şekilde ifade etmiştir:

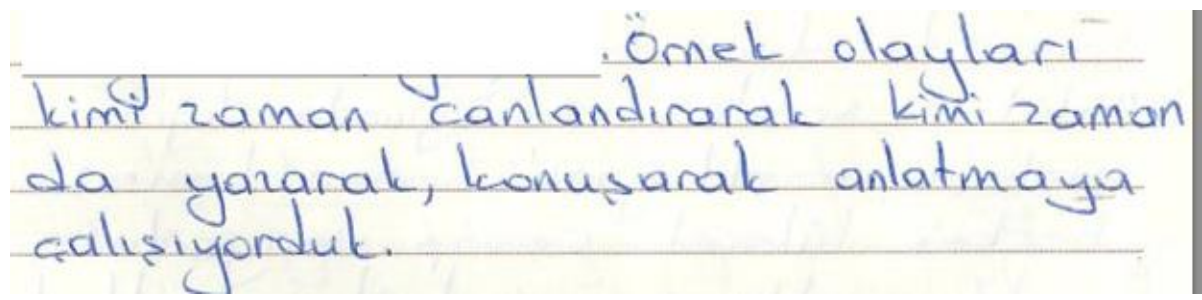

Verilen örnek olay incelemesi temelli eğitimin ardından öğretmenlerin örnek olay kullanarak işleyecekleri 6 ders için, örnek olay metinlerinden 4'ü araştırmacı tarafından hazırlanmış, son 2'sinin ise öğretmenler tarafından ikili gruplar halinde çalışarak hazırlanması istenmiştir. Bu süreçte öğretmenlerin hazırladıkları örnek olay metinlerinin özellikleri, soracakları sorular ve kullanacakları etkinlikler konusunda araştırmacı tarafindan dönütler verilerek 


\section{Dr. Nur ÜTKÜR / Prof. Dr. Yücel KABAPINAR}

yeniden düzenleme yapılması sağlanmıştır. Öğretmenlerin bu süreçte yaşadıklarına günlüklerinde yer alan verilerden ulaşılmış olup görüşlerine Tablo 2'de yer verilmiştir.

Tablo 2. Eğitim Sonrasındaki Örnek Olay Hazırlama Sürecine Yönelik Öğretmen Görüşleri

\begin{tabular}{|c|c|c|}
\hline $\begin{array}{l}\text { Ana } \\
\text { Temalar }\end{array}$ & Alt Temalar & $\begin{array}{c}\text { Sayı } \\
\text { (f) }\end{array}$ \\
\hline \multirow{7}{*}{$\begin{array}{l}\text { Olumlu } \\
\text { Noktalar }\end{array}$} & Dönütlerle Desteklemenin Yapılması & 5 \\
\hline & Kiși Ve Olay Kurgusunun Rahatlıkla Yapılabilmesi & 4 \\
\hline & Yaşanmış Olaylardan Esinlenilmesi & 2 \\
\hline & Önceki Örnek Olaylardan Yararlanılması & 2 \\
\hline & Eğitim Materyallerinden Yararlanılması & 2 \\
\hline & Diğer Derslere Transfer Yapma İsteği Yaşanması & 1 \\
\hline & Ara Toplam & 16 \\
\hline \multirow{6}{*}{$\begin{array}{l}\text { Zorluk } \\
\text { Çekilen } \\
\text { Noktalar }\end{array}$} & Çatışma İçeren Olay Yazma & 4 \\
\hline & Çözümün Örnek Olay İçinde Yer Almamasına Dikkat Etme & 3 \\
\hline & Düşünsel-Empatik-Ahlâkî Soru Sormaya Uygun Olay Yazma & 2 \\
\hline & Yönlendirme Yapmamaya Dikkat Etme & 2 \\
\hline & Ara Toplam & 11 \\
\hline & Genel Toplam & 27 \\
\hline
\end{tabular}

Tablo 2'de yer alan veriler, öğretmenlere verilen eğitim sonrasındaki öğretmenlerin kullandıkları örnek olaylara ve bunları hazırlama süreçlerine yöneliktir. Bu görüssler "olumlu noktalar" ve "zorluk çekilen noktalar" şeklindedir. Öğretmenlerin olumlu gördükleri noktaların alt temalanı incelediğinde; örnek olay metinleri yazarken öğretmenlerden 5 'inin "dönütlerle desteklenmeyi" beğendiğini, 4'ünün "kişi ve olay kurgusunu rahatlıkla yapabildiklerini”, 2'sinin “yaşanmış olaylardan esinlendiklerini”, 2'sinin “önceki örnek olaylardan yararlandıklarını", 2'sinin "eğitim materyallerinden yararlandıklarını" ve 1'inin ise örnek olay metinlerinin yazarken "diğer derslere transfer yapma isteği yaşadığını" belirttikleri tespit edilmiştir.

Öğretmenlerden 5'i örnek olay metinlerini yazarlarken en çok araştırmacı tarafından "kendilerine dönüt verilmesini" beğendiklerini ifade etmişlerdir. Bu konuda görüş belirten devlet okulu öğretmenlerinden DÖ1 günlüğünde şunları yazmıştır:

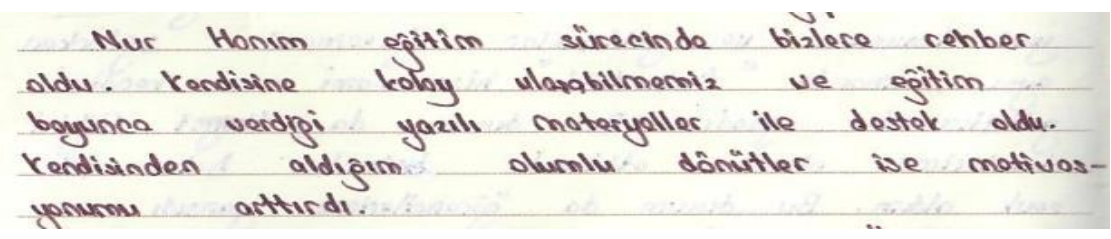


DÖ1 eğitim süreci ve örnek olay metinlerini yazma boyunca araştırmacıdan aldığı destekten memnun kaldığını ve bu durumun motivasyonunu arttığını belirtmiştir. Öğretmenlerden 4'ü örnek olay yazma sürecinde "kişi ve olay kurgusunun rahatlıkla yapabilmelerinden" mutlu olduklarını ifade etmiştir. Bu konuda görüş bildiren özel okul öğretmenlerinden ÖÖ3;

$$
\begin{aligned}
& \text { örnek olay olustururken, kisileri kurgulamakta, } \\
& \text { olaylari kurgutimakta zorlanmadem. }
\end{aligned}
$$

şeklinde düşüncelerini ifade etmiştir. Öte yandan devlet okulu öğretmenlerinden DÖ2'nin bu süreçte yaşadıklarına yönelik günlügünde belirttikleri "yaşanmış olaylardan esinlendiğini" göstermektedir. Öğretmen bu konuda şunları yazmıştır:

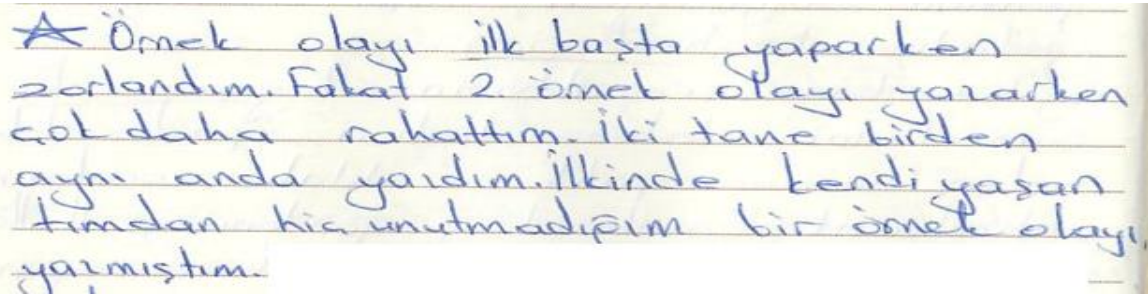

Örnek olay metinlerini yazarken başlarda zorlandığını ifade eden öğretmen, araştırmacının dönütleri sonrası ikinci örnek olaya geçtiğinde rahatladığını belirtmiştir. Kendi yaşantısından hiç unutamadığı olayları, yazdığı örnek olaylarda kullandığından bahsetmiştir. Diğer öğretmenlerin de bu süreçte "zorlandıkları noktalar" incelendiğinde öğretmenlerden 4'ünün "çatışma içeren olay yazma", 3'ünün "çözümün örnek olay içinde yer almaması", 2'sinin "düşünsel, ahlâkî ve empatik soru sormaya uygun örnek olay yazma" ve yine 2'sinin "yönlendirme yapmamaya özen gösterme" konularında sorunlar yaşadıkları belirlenmiştir. "Çatışma içeren örnek olay yazma" konusunda sorun yaşayan öğretmenlerden bir diğeri devlet okulu öğretmenlerinden DÖ2'dir. Öğretmen yazdığ1 örnek olaylarda çatışma içeren ikili durumlar olmadığ 1 için sorun yaşadığını ve araştırmacıyla birlikte bu sorunu aştıklarını günlüğünde ifade etmiştir. Öğretmenlerin örnek olay metinleri yazarken yaşadıkları sorunlardan bir diğeri, "çözümün örnek olay içinde yer almamasına" dikkat edilmesidir. Özel okul öğretmenlerinden ÖÖ3 bu konudaki görüşlerini günlüğünde şu şekilde ifade etmiştir: 


\begin{tabular}{|c|}
\hline Günkü o"grenci kendisi' \\
\hline igi kötu, Jogru, yanlis konwunda sec \\
\hline Karar ögrencide olmalyde metinden düsündüblerigy \\
\hline
\end{tabular}

Öğretmen örnek olay metinlerini yazma sürecinde çözüm yolunun örnek olay içinde yer almamasına yönelik sorun yaşadığını belirtmiştir. $\mathrm{Bu}$ noktada öğretmen karşılaştığı bu sorundan sonra araştırmacıdan yardım ald1ğını ve örnek olayı ona göre şekillendirdiğini ifade etmiştir. Öğretmen iyi-kötü, doğru-yanlış çıkarımlarına öğrencinin kendisinin varması gerektiğini fark ettiğini belirterek bu konudaki görüşlerini günlüğünde yazmıştır.

Öğretmenlerin örnek olay yazma sürecinde zorlandıkları bir diğer noktanın ise, "yönlendirme yapmamaya dikkat etme" olduğu belirlenmiştir. Bu konuda görüş belirten özel okul öğretmenlerinden ÖÖ4 günlügünde şunları yazmıştır:

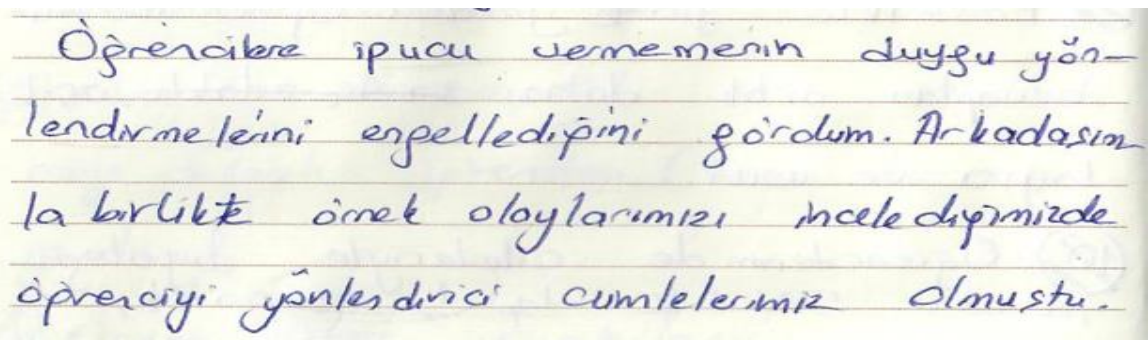

Öğretmen örnek olay metinlerini, öğrenciyi yönlendirici ya da onlara doğruyu direkt gösterici cümleleri içermeyecek şekilde yazma konusunda sıkıntı yaşadığını dile getirmiştir. Bu nedenle örnek olay metinlerini ikili olarak çalışarak yazarken, ipucu vermeme, yönlendirmemeye dikkat etme gibi konularda zorlandığını ifade etmiştir. Öğretmen örnek olay metinlerini yazarken özellikle açıkça ortada olan konularda ipucu vermenin öğrencileri yönlendirici bir konu olduğunu fark etmiştir.

Elde edilen bu bulgularda, öğretmenlerin verilen eğitim öncesinde kullandıkları ve eğitim sonrasında kendilerinin oluşturdukları örnek olaylara yönelik görüşleri incelenmiş ve analiz edilmiştir. Bu analizler doğrultusunda, özel okul ve devlet okulu öğretmenlerinin eğitim öncesinde kullandıkları 
örnek olayları genel olarak yetersiz buldukları tespit edilmişken; eğitim sonrasında araştırmacıdan yardım alarak kendi oluşturdukları örnek olay metinlerine yönelik görece daha olumlu düşünceler taşıdıkları tespit edilmiştir. Aynı zamanda öğretmenlerin eğitim öncesinde kullandıkları örnek olayları da eğitimde edindikleri nitelikli örnek olayın özellikleri doğrultusunda eleştirdikleri, kendi örnek olaylarını da bu özellikler doğrultusunda yazmaya çalıştıkları gözlemlenmiştir. Bu bölümde elde edilen bulguların önemi, öğretmenlerin verilen eğitimin kendileri üzerindeki etkisini fark etmelerinin tespit edilmesidir. Ayrıca öğretmenlerin örnek olay yazma sürecinde olumlu ya da olumsuz yaşadıklarını ifade etmeleri, kendilerini analiz edebilmeleri bakımından da önem taşımaktadır.

\section{Ĕ̆itim Sonrasında Öğretmenler Tarafından Oluşturulan Örnek Olay Metinlerinin Niteliği}

Öğretmenlerden verilen eğitim sonrasında verilen konu ve kazanımlar doğrultusunda ikişerli çalışarak örnek olay metinleri oluşturmaları istenmiştir. Özel okuldaki 4 öğretmen ikişerli çalışarak her grup için birer adet örnek olay metni ortaya koyarken; devlet okulundaki 3 öğretmenin her biri ayrı ayrı örnek olay metinleri oluşturmuş̧ur. Araştırmacıdan dönüt alınıp gerekli düzeltmeler yapıldıktan sonra, öğretmenlerin ortaya koydukları toplam örnek olay metni sayıs 10 'dur.

Araştırma sorusunun cevabına ulaşmak için, öğretmenlerin eğitim sonrasında oluşturdukları örnek olay metinleri, Davis'in (1993) nitelikli bir örnek olay metninde bulunmasını öngördüğü özellikler (akt; Beckisheva, Gasparyan ve Kovalenko, 2015) göz önüne alınarak analiz edilmiştir. Araştırmacı tarafindan dönüt verildikten sonraki örnek olay metinleri doküman inceleme yöntemiyle ele alınmış olup, analizden sonra elde edilen veriler Tablo 3'te bulunmaktadır.

Tablo 3. Öğretmenlerin Oluşturdukları Örnek Olay Metinlerinin Özellikleri

\begin{tabular}{lc}
\hline Temalar & Örnek Olay Sayısı (f) \\
\hline Gerçek Hayattan Alınmış Özellikler Taşıması & 10 \\
Karakterlerle Empati Kurulabilmesi & 10 \\
Karakter, Yer ve Olay Hakkında Bilgi Vermesi & 10 \\
Düşünmeyi ve Tartışmayı İçermesi & 9 \\
Çatışma İçeren Durumlar Barındırması & 9 \\
Sonucunun Net Olarak Belli Olmaması & 8 \\
Kısa ve Öz Olması & 5 \\
\hline Toplam & 61 \\
\hline
\end{tabular}


Tablo 3'te yer alan veriler incelendiğinde, öğretmenlerin oluşturdukları örnek olay metinlerinin tamamının "gerçek hayattan alınmış özellikler taşıdığı, karakterlerle empati kurulmasına olanak sağladığı ve karakter, yer, olay hakkında bilgi verdiği”" tespit edilmiştir. Ortaya konulan metinlerden 9'unun "düşünme ve tartışmayı içerirken, çatışma içeren durumlar barındırdığı"; 8 'inin ise "sonucunun net olarak belli olmadığ ortaya koydukları örnek olayların yarısının "kısa ve öz olma" kriterine uyabildiği tespit edilmiştir.

"Gerçek hayattan alınmış özellikler taşıması" ile ilgili olarak öğretmenlerin yazdıkları metinler incelendiğinde, öğrencilerin sınıf ortamında, aile içinde ve arkadaş çevresinde karşılaşabilecekleri durumlar içeren olayları ele aldıkları tespit edilmiştir. Devlet okulu ve özel okul öğretmenlerinin yazdıkları metinlerden kesitlere aşağıda yer verilmiştir.

DÖ1'in yazdığ1 örnek olayın "gerçek hayattan alındığına yönelik" bir kesit:

\begin{tabular}{|c|c|c|c|c|c|c|}
\hline & & Nasil & Galisabil & irim & $?$ & \\
\hline & aru' nun & ögretmeni & " & canlilarin & "Ozellikleri & konulu \\
\hline bic & arastirma & ödevi & vermists. & Alyn & $2 a m a n d a$ & matematis \\
\hline dersi & iain & ¿omesi & eltigi & problem & ödevi & vardl. \\
\hline
\end{tabular}

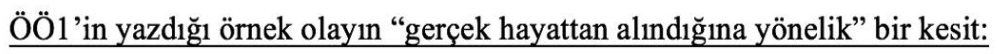

Leylo'inn okulunda bir komponyo basatimistt. Kimsesiz ve yordima muhtac couklo destek olmak, onlaro yordim etmek amacylo herkes evinden kükülen glysilerin, kullon. madklari kitup, defter ve oyuncoklarinı getirecekti.

Devlet okulu öğretmenlerinden DÖ1, Duru adındaki bir öğrencinin öğretmeninin verdiği ödevleri nasıl yapacağını ve özel okul öğretmenlerinden ÖÖ1, Leyla adındaki bir öğrencinin okulunda kimsesiz çocuklar için bir kampanya başlatılmasını konu alan birer örnek olay yazmışlardır. Bu olayların gerçek hayattan alındığı görülmekte ve her öğrencinin okul ortamında bunları yaşayabildiği bilinmektedir. Bu sayede örnek olayları okuyan, içinde bulunan çatışma ve sorunları çözmeye çalışan öğrencilere yaşamlarından tanıdık olaylar sunularak zorlanmaları engellenmiş olmaktadır. 
Öğretmenlerin yazdıkları örnek olayların tümünde "karakterlerle empati kurulmasına olanak sağlayan" unsurların bulunmakta olduğu tespit edilmiştir. Öğrencilerin metinlerdeki karakterlerin yaşadıkları olayları anlamalarını, kendi yaşantılarından benzerlikler bularak onların hissettiklerini hissetmelerini sağlayıcı durumlar olduğu belirlenmiştir. Devlet okulu ve özel okuldaki öğretmenlerin yazdıkları örnek olaylardaki bahsedilen durumlara aşağıdan ulaşılabilmektedir.

\section{DÖ3'ün örnek olayından "karakterlerle empati kurulabilmesine" yönelik bir kesit:}

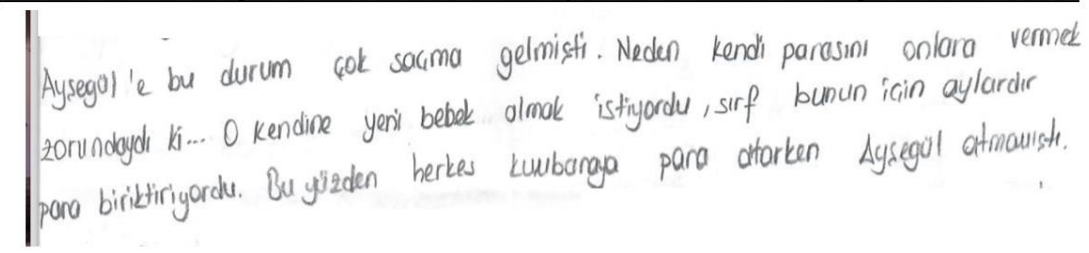

ÖÖ3'ün örnek olayından "karakterlerle empati kurulabilmesine" yönelik bir kesit: $\mathcal{A}$ li akșam haberlerinde Van depremi haberini dinlediğini, oradaki köyde yaşayan öğrencilerin okullarnnda bir çok eksik olduğunu, bu yüzden öğrencilerin çok sıkintı çektiğini anlattr. Ayșe de gel bunu simf arkadaşlarımızla paylaşalım dedí. Bahçede Esin ve Ayhan; "Bize ne onlardan, Gaşlarmın çaresine baksınlar" dediler.

Devlet okulu öğretmenlerinden DÖ3, örnek olayında Ayşegül adlı bir kızın yardıma ihtiyacı olan çocuklar için toplanan para yardımına, kendine almak istediği bebek yüzünden katılmak istemediğini anlatmıştır. Özel okul öğretmenlerinden ÖÖ3 ise, depremzedelere yardım etmek isteyen ve istemeyen bir grup öğrenciye yönelik bir örnek olay yazmıştır. Her iki örnek olaydan alınan durumlar da, öğrencilerin belirtilen karakterlerle empati kurabilmelerine yöneliktir. Öğrenciler kendilerini olaylardaki karakterlerin yerine koyup, onlar gibi düşünüp, onlar gibi hissederek bu konularda neler yapabileceklerini ifade etmişlerdir.

Öğretmenlerin yazdıkları örnek olayların 9'unda “çatışma içeren durumların" bulunduğu tespit edilmiştir. Devlet okulu ve özel okuldaki öğretmenlerin yazdıkları örnek olaylardan bu durumla ilgili kesitlere aşağıdan ulaşılabilmektedir: 


\section{DÖ2'nin örnek olayında "çatışma olduğuna" yönelik bir kesit:}

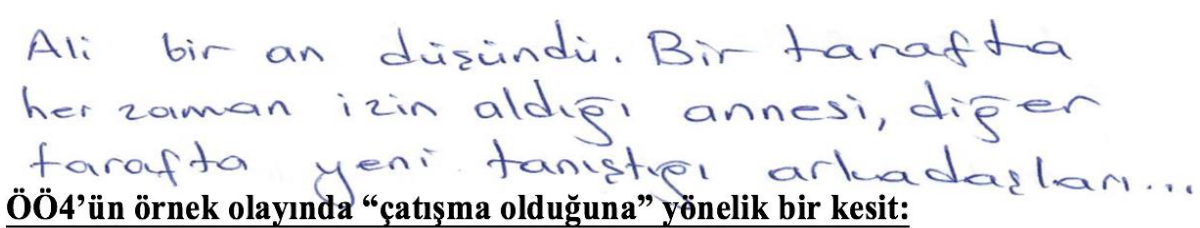

Meltem'in anne-babası tatilden döndüklerinde çok kızmıştı. Bir daha kesinlikle eve arkadaşlarını çağırması yasaktı... Ama Cansu ve diğer arkadaşları da kendilerini çağırmazsa, onunla bir daha hiç konuşmayacaklarını, onu hiçbir oyuna almayacaklarını söylemişlerdi.

DÖ2'nin örnek olayında, arkadaşları ve annesi arasında kalan Ali'nin, annesinden azar işitmek ve bir daha kendisiyle oyun oynanmaması durumlarından hangisini seçeceğine yönelik bir çatışma işlenirken; ÖÖ4'ün örnek olayında ise benzer durum Meltem adlı kızın ailesi ve arkadaşları arasında kalmasına yönelik ele alınmıştır. Böylece öğrencilerin bu çatışma durumlarından hangilerinin seçilebileceği konusunda fikir üretmeleri sağlanarak, tartışma ortamı oluşturulmuştur.

Öğretmenlerin yazdıkları örnek olayların 8'inde "sonucun belli olmadığı" belirlenmiştir. Örnek olayların sonucunun belli olmaması, öğrencilerin olaylardaki problemlere yönelik farklı çözüm yolları üretebilmelerine yardımcı olmaktadır. Devlet okulu ve özel okuldaki öğretmenlerin yazdıkları örnek olaylardan bu durumla ilgili kesitlere aşağıda yer verilmektedir:

Dö1'in örnek olayindan "sonucun belli olmamasina" yönelik bir kesit:
O sisada vmut, un bobass da dondurmay' arkadastorina
dop̧ru getivordu. Sinom elindoks silise bakakaldi...

\section{ÖÖ2'nin örnek olayından "sonucun belli olmamasına" yönelik bir kesit}

\section{Ela bir taraftan ayni seyin kendí basina gelmassinden korkuyor, digar} taraftan da sinavdan kotu not alirsa, ailesi ve ögretmeninin ne kodar üzüleccogini düsünüyordu. Ne yapacaĝnı bilemez bir haldaydi...

Devlet okulu öğretmenlerinden DÖ1'in örnek olayında Sinem adlı bir kızın ezberlemesi gereken şiirle, bahçede oynayan arkadaşlarının yanına gitmek arasında kalmasına yönelik bir olay anlatılmış, ancak sonucun ucu açık bırakılmıştır. Yine özel okul öğretmenlerinden ÖÖ2'nin örnek olayında 
ise Ela'nın arkadaşları ve ailesi arasında kalmasına yönelik bir durum ele alınmış, sonuçta hangisine tercih ettiğine yer verilmemiştir. Örnek olayların bu şekilde sonuçlarının belli olmaması, öğrencilerin kendilerine göre sonuç üretebilmelerini ve bu konu üzerinde tartışabilmeyi sağlamıştır. Tüm bu veriler doğrultusunda verilen eğitim sonrasında yazılan örnek olay metinlerinin özellikleri genel olarak incelendiğinde, nitelikli bir örnek olayın özelliklerine uygun oldukları tespit edilmiştir.

\section{Öğretmenlere Verilen Eğitim Öncesindeki ve Sonrasındaki Sınıf Orta- mına İlişkin Öğretmen Görüşleri Nelerdir?}

Öğretmenlere verilen eğitim sonrasında 6'şar ders saati daha gözlemlenmiştir. Öğretmenlerin, eğitim ve eğitim sonrası durum hakkındaki görüşlerini öğrenebilmek amacıyla açık uçlu son algı anketi uygulanmış, ayrıca öğretmen günlükleri analiz edilmiştir. Elde edilen verilerin birbirini destekler nitelikte olduğu tespit edilmiş ve bunlara Tablo 4'ten ulaşılabilmektedir.

Tablo 4'te yer alan veriler incelendiğinde öğretmenlerin "kendilerine" yönelik gelişimleriyle ilgili olan alt temalara yönelik görüşlerin toplam 29 olduğu, "öğrencilere" yönelik gelişimleriyle ilgili olan görüşlerin ise toplam 19 olduğu belirlenmiştir.

Öğretmenlerin "kendilerine yönelik gelişimleri” temasında yer alan alt temalarda öğretmenlerin tümü eğitim sonrasında "düşünsel, ahlâkî ve empatik soruların dengelendiğini” düşünürken, öğretmenlerin 4'ü "örnek olay oluşturulabileceğinin fark edilmesi" ve "örnek olay yönteminin dersin içine sokulması" konusunda fikirlerini ifade etmiştir. Öğretmenlerin 3'ü ise "açık, net ve uzun cevaplı soru sorulmasının öneminin kavranması" ve "ürünlerin sergilenip değerlendirilmesinin öneminin kavranması" konusunda düşüncelerini belirtirken, 2'si "örnek olayla ilgili etkinlik oluşturulabilmesi" konusunda görüşlerini ortaya koymuştur. Öğretmenlerin kendilerine yönelik gelişimleriyle ilgili olarak sadece bir öğretmenin görüş belirttiği 6 farklı kategori bulunmaktadır. Bunlar, "yaratıcılığın geliştiğinin fark edilmesi, farkındalık kazandırılması, Hayat Bilgisi derslerinden zevk alınması, konuyla sorular arasında bağlantı kurulabilmesi, kitaplardaki örnek olay metinlerinin yetersizliğinin fark edilmesi ve farklı derslere transfer edilebilmesi” şeklindedir. 


\section{Dr. Nur ÜTKÜR / Prof. Dr. Yücel KABAPINAR}

Tablo 4. Örnek Olay İncelemesi Temelli Eğitim Sonrasına Yönelik Öğretmen Görüşleri

\begin{tabular}{llc}
\hline $\begin{array}{l}\text { Ana } \\
\text { Temalar }\end{array}$ & Alt Temalar & $\begin{array}{c}\text { Sayı } \\
\text { (f) }\end{array}$ \\
\hline & Düşünsel, Ahlâkî ve Empatik Soruların Dengelenmesi & 7 \\
& Örnek Olay Oluşturulabileceğinin Fark Edilmesi & 4 \\
& Örnek Olay Yönteminin Dersin İçine Sokulması & 4 \\
& Açık, Net ve Uzun Cevaplı Soru Sorulmasını Önemi- & 3 \\
nin Kavranması & \\
Kendilerine & Ürünlerin Sergilenip Değerlendirilmesinin Öneminin & 3 \\
Yönelik & Kavranması & \\
Gelişim & Farkındalık Kazandırması & 3 \\
& Örnek Olayla İlgili Etkinlik Oluşturulabilmesi & 2 \\
& Yaratıc1lı̆̆ın Geliştiğinin Fark Edilmesi & 1 \\
& Hayat Bilgisi Derslerinden Zevk Alınması & 1 \\
& Konuyla Sorular Arasında Bağlantı Kurulabilmesi & 1 \\
& Kitaplardaki Örnek Olay Metinlerinin Yetersizliğinin & 1 \\
& Fark Edilmesi & 1 \\
\hline & Farklı Derslere Transfer Edilebilmesi & $\mathbf{2 9}$ \\
\cline { 2 - 3 } & Ara Toplam & 5 \\
& İlgi ve Motivasyonlarının Artması & 4 \\
& Derse Katıllımlarının Artması & 4 \\
Öğrencilere & Yaşantılarından Değerlerle Karşlaşmaları & 2 \\
Yönelik & Nitelikli ve Açıklayıcı Cevap Verebilmeleri & 2 \\
Gelişim & Empatik ve Ahlâkî Sorulara Cevap Verebilmeleri & 1 \\
& Sorunlara Farklı Perspektifle Çözüm Bulabilmeleri & 1 \\
& Aileleriyle Diyaloglarında Empatik-Ahlâkî Soru Kul- & 1 \\
& lanabilmeleri & $\mathbf{1 9}$ \\
\cline { 2 - 3 } & Ara Toplam & $\mathbf{4 8}$ \\
\hline & Genel Toplam & \\
\hline
\end{tabular}

İlk olarak öğretmenlerin tamamının eğitim sonrasında kendilerinde gördükleri gelişimle ilgili olarak belirttikleri bir alt tema olan "Düşünsel, ahlâkî ve empatik soruların dengelenmesi” kategorisi incelendiğinde, özel okul öğretmenlerinden ÖÖ2'nin bu konudaki düşüncesini şu şekilde ifade ettiği görülmüsstür:

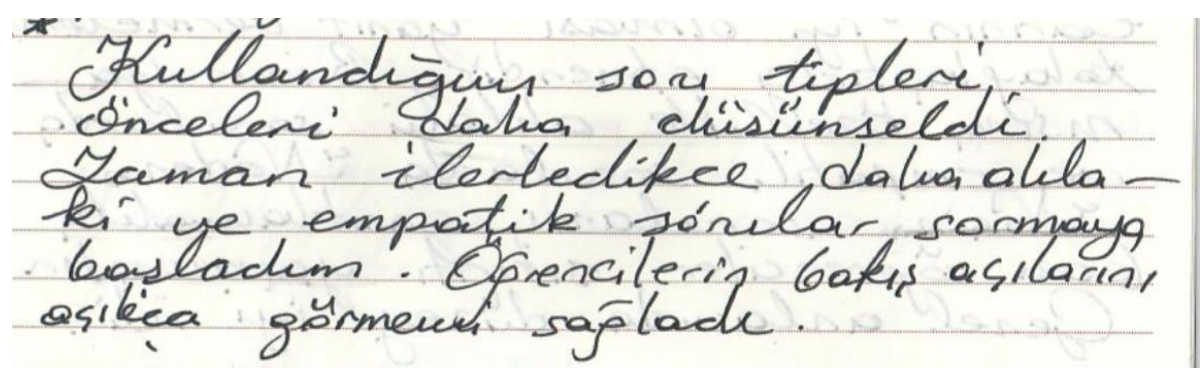


ÖÖ2'nin günlüğünde yazdıkları incelendiğinde, öğretmenin eğitim öncesine göre eğitim sonrasında ahlâkî ve empatik sorulara daha fazla ağırlık verdiği tespit edilmiştir. Öğretmene göre bu durumun onun öğrencilerin bakış açılarını açıkça görmesini sağlayan bir durum hâline geldiği görülmektedir.

Öğretmenlerin ikinci sırada görüş bildirdikleri alt temalardan bir diğeri olan "örnek olay yönteminin dersin içine sokulması" ile ilgili olarak özel okul öğretmenlerinden ÖÖ4'ün görüşlerine bakıldığında örnek olay yöntemini derslerde kullanmanın ne derece önemli olduğuna değindiği ve bunu toplumsal sorunlarla ilişkilendirdiği görülmektedir. Öğretmen örnek olay yöntemini derslerin içine sokabilmenin olaylar üzerinde tartışmayı sağlayacağını ve düşünebilen, sorgulayabilen insanlar yetiştirebileceğini ortaya koymaktadir.

Öğretmen örnek olay yöntemi kullanılarak ders işlemenin, örnek olay yazıp, sorular, etkinlikler oluşturmanın yaratıcılığını geliştirdiğini düşünmektedir. Aynı zamanda bundan sonraki derslerinde de bu yöntemi kullanmaya devam edeceğini belirtmiştir. Öğretmenlerden yine bir kişinin görüş belirttiği diğer bir alt temanın ise, örnek olay yöntemiyle ilgili öğrenilenlerin "farklı derslere transfer edilebilmesi" olduğu belirlenmiştir. Bu konuyla ilgili olarak özel okul öğretmenlerinden ÖÖ4'ün görüşlerine aşağıda yer verilmektedir:

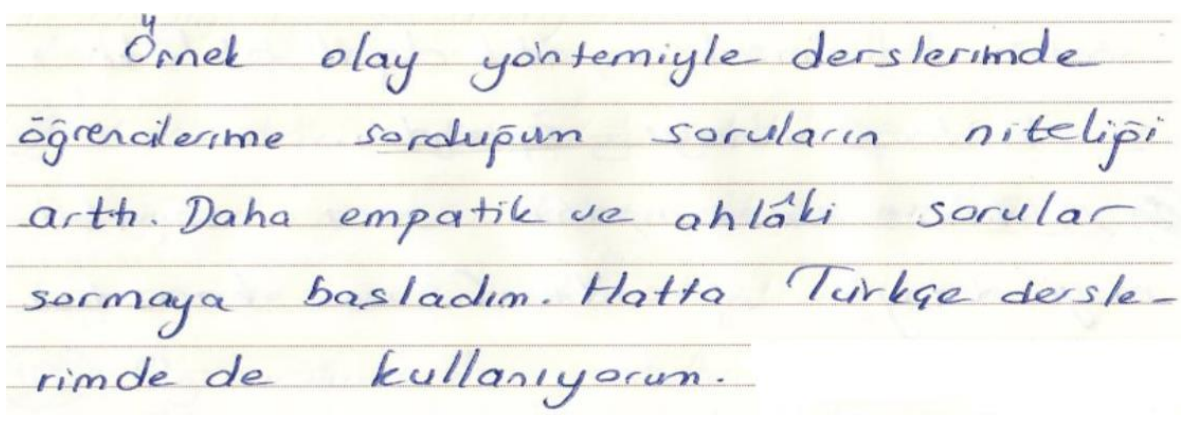

Öğretmen Hayat Bilgisi derslerinde örnek olay incelemesi yönteminin kullanılmasına ilişkin aldığı eğitim sonrasında, empatik ve ahlâkî soruları daha çok kullanmaya başladığını, aynı zamanda öğrendiklerini Türkçe derslerinde de uyguladığııı ifade etmiştir.

Örnek olay incelemesi temelli eğitimin verilmesinin ardından öğretmenlerin gördükleri "öğrencilere yönelik gelişmelerin" alt temaları incelendiğinde, öğretmenlerin beşinin "ilgi ve motivasyonlarının artması", 4’ünün 
"derse katılımlarının artması ve yaşantılarından değerlerle karşılaşmaları", 2'sinin"nitelikli ve açıklayıcı cevap verirken ahlâkî ve empatik sorulara da cevap verebildikleri” ve öğretmenlerden 1'er kişinin "sorunlara farklı perspektifle çözüm bulabilmeleri” ve "aileleriyle diyaloglarında empatik-ahlâkî soru kullanabilmeleri” ile ilgili görüş belirttikleri tespit edilmiştir.

İlk olarak öğretmenlerin beşinin eğitim sonrasında öğrencilerde gördükleri gelişimle ilgili olarak belirttikleri bir alt tema olan "ilgi ve motivasyonlarının artmasına" yönelik görüşlerden devlet okulu öğretmenlerinden DÖ1'inkilere aşağıdan ulaşılabilmektedir.

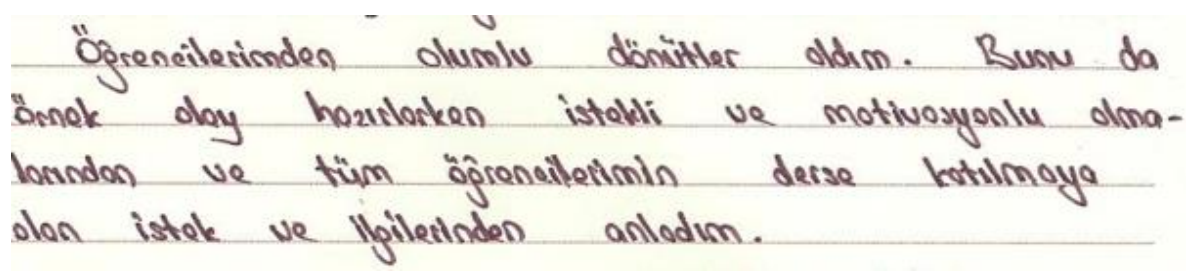

Öğretmen örnek olay incelemesi yöntemi kullanarak ders işledikten sonra öğrencilerinden olumlu dönütler aldığını belirtirken; öğrencilerin "ilgi ve motivasyonlarının arttığını” ifade etmiştir. Tüm öğrencilerin derse katılmak için önceye göre daha istekli olduğunu belirtmiştir. Öğretmenin bu durumu belirtmesi, öğrencilerde gördüğü farkı tespit ettiği anlamına gelmektedir. Örnek olay incelemesi yöntemini kullanmanın öğrencilerin motivasyonunu arttırdığ 1 öğretmen tarafından düşünülmektedir.

Ayrıca öğretmenlerden 2'si öğrencilerin sorulan sorulara "nitelikli ve açıklayıcı cevaplar" verebildiklerini, aynı zamanda "empatik ve ahlâkî sorulara da cevap verebildiklerini” belirtmişlerdir. Verilen eğitimde öğretmenlere söylenen ve dikkat edilmesi istenen bir nokta, öğrencilerin genelde sorulara kısa cevaplar verdikleri, öğretmenlerin bunların daha uzun ve nitelikli olmasını sağlayıcı şekilde sorular sormaları gerektiği yönündedir. Bundan dolayı ÖÖ4 görüşlerinde, eğitim sonrasında sorduğu sorulara öğrencilerin verdiği cevapları incelemiş ve bunların daha uzun ve açıklayıcı olduğunu ifade etmiştir. Özel okul öğretmenlerinden bir diğeri olan ÖÖ3'ün "empatik ve ahlâkî sorulara cevap vermeleriyle" ilgili olarak görüşü ise şu şekildedir: 


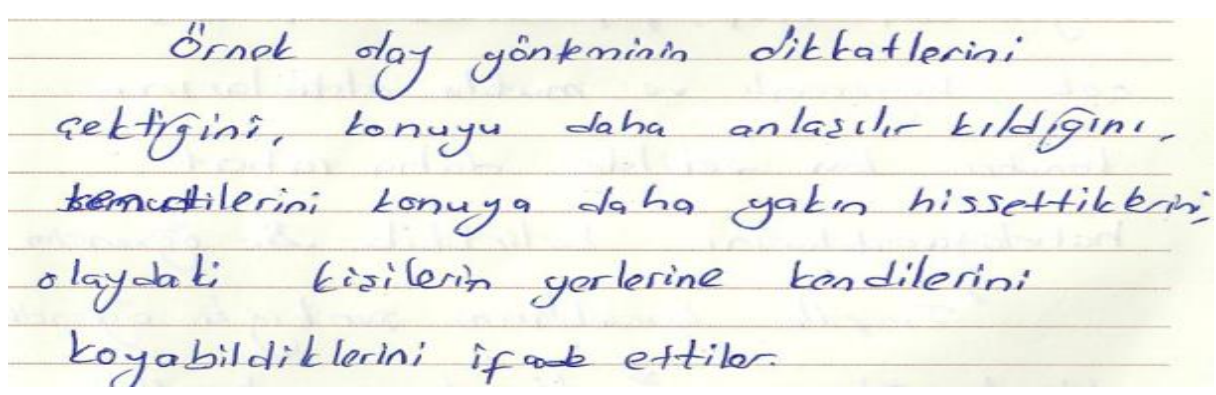

ÖÖ3 örnek olay incelemesi yönteminin kullanılmasıyla öğrencilerin dikkatlerinin daha iyi çekildiği yönünde fikir belirtirken; empatik soruların sorulması sonucu kendilerini olaydaki kişilerin yerine koyup, daha rahat hissettiklerinden rahat cevaplar verebildiklerini düşünmektedir. Öğretmen bir olay üzerinden gidildiğinde gerek empatik gerekse de ahlâkî sorulara cevap vermenin daha kolay olacağını ifade etmektedir.

Öğretmenlerin verilen eğitim öncesi ve eğitim sonrası duruma ilişkin görüşlerinin neler olduğunun incelendiği bu araştırma sorusunun cevabı iki kısımda ele alınmıştır. Verilen eğitim sonrasında öğretmenlerin kendilerine ve öğrencilerine yönelik gelişimleriyle ilgili belirttiği görüşler incelenmiş; öğretmenlerin her iki temada da belirgin değişikliklerin olduğunu düşündükleri tespit edilmiştir.

\section{Sonuç ve Tartışma}

Bu çalışmada öğretmenlere verilen örnek olay incelemesi temelli eğitim sonrasında, öğretmenlerin kullandıkları örnek olay metinlerinin niteliğine yönelik görüşlerinin alınması ve kendilerinin oluşturdukları metinlerin incelenmesi amaçlanmıştır.

Öğretmenlerin verilen eğitim öncesinde Hayat Bilgisi derslerinde kullandıkları örnek olayların yetersiz olduğunu düşündükleri tespit edilmiş ve bunları derslerde kullanırken canlandırma, soru-cevap ve başından geçen benzer olayın anlatılması etkinliklerine yer verdikleri sonucuna ulaşılmıştır. Öğretmenler verilen eğitim sonrasında kullandıkları örnek olaylara yönelik görüşlerini belirtirken, kendi örnek olaylarını hazırlama sürecine yönelik düşüncelerini ifade etmişlerdir. Bu düşüncelerinde öğretmenler eğitim sonrasında kendi örnek olaylarını yazma sürecindeki olumlu noktaları ve zorluk çektikleri noktaları belirtmişlerdir. Öğretmenlerin örnek olay hazırlama sürecinde olumlu buldukları kısımların "araştırmacı tarafından dönütlerle desteklemenin yapılması, kişi ve olay kurgusunun rahatlıkla yapılabilmesi, 
yaşanmış olaylardan esinlenilmesi, araştırmacının hazırladığı örnek olaylardan ve eğitim sırasında verilen materyallerden yararlanılması, diğer derslere transfer yapma isteği yaşanması" şeklinde olduğu sonucuna ulaşılmıştır.

Öğretmenlerin bu süreçte zorluk çektikleri kısımların ise "çatışma içeren örnek olay yazabilme, çözümün örnek olay içinde yer almamasına dikkat etme, düşünsel, empatik, ahlâkî soru sormaya uygun olay yazabilme, örnek olay metinlerinde yönlendirme yapmamaya dikkat etme" şeklinde olduğu tespit edilmiştir. Öğretmenlere verilen eğitim sonrasında öğretmenler tarafından yazılan örnek olayların özellikleri incelendiğinde, bu örnek olayların nitelikli bir örnek olayın özelliklerine uyduğu sonucuna ulaşılmıştır. Öğretmenlerin yazdığı örnek olaylar "gerçek hayattan özellikler taşıması, karakterlerle empati kurulabilmesi, karakter, yer ve olay hakkında bilgi vermesi, düşünme ve tartışmayı içermesi, çatışma içeren durumlar barındırması, olayda yer alan sonucun net olarak belli olmaması, olayın kısa ve öz olması" şeklindeki özelliklerinden ötürü nitelikli örnek olay olma özelliği taşımaktadırlar. Öğretmenlerin yazdıkları örnek olay metinleri Davis'in (1993) nitelikli örnek olay özellikleri doğrultusunda incelendiğinde, "gerçek hayattan özellikler taşıması, karakterlerle empati kurulabilmesi, karakter, yer ve olay hakkında bilgi vermesi, düşünme ve tartışmayı içermesi, çatışma içeren durumlar barındırması, olayda yer alan sonucun net olarak belli olmaması, olayın kısa ve öz olması" gibi özellikleri nedeniyle nitelikli bulunmuştur (akt; Beckisheva, Gasparyan ve Kovalenko, 2015).

Öğretmenlerin verilen eğitim öncesi ve sonrasındaki sınıf ortamına ilişkin görüşlerinin kendilerine yönelik ve öğrencilere yönelik birtakım gelişmelerin olduğunu tespit ettiklerine yöneliktir. Öğretmenlerin verilen örnek olay temelli eğitim sonrasında kendilerinde gördükleri gelişimler, "empatik ve ahlâkî soruların kullanımının artması ve düşünsel soru kullanımıyla dengelenmesi, kullanılan soru niteliğinde gelişim sağlanması, açık uçlu soru sorulmasının öneminin fark edilmesi, derslerdeki ürün sergileme ve değerlendirme sürecinin öneminin fark edilmesi, örnek olay oluşturulabileceğinin ve sınıfta kullanılabileceğinin farkına varılması, kullanılan örnek olayları seçmede gelişim sağlanması, etkinlik oluşturulabilmesi, yaratıcılığın geliştiğinin fark edilmesi, Hayat Bilgisi derslerinden zevk alınması, kitaplardaki örnek olayların yetersizliğinin fark edilmesi, örnek olay yönteminin farklı derslere transfer edilebilmesi” şeklindedir.

Öğretmenlerin verilen örnek olay temelli eğitim sonrasında 
öğrencilerde gördükleri gelişimlerin ise, "ilgi ve motivasyonların, derse kat1lımın artması, derslerde daha çok eğlenilmesi, yaşantılarından değerlerle karşılaşmaları, empatik ve ahlâkî sorulara nitelikli ve açıklayıcı cevaplar vermeleri, sorunlara farklı perspektiflerle çözüm bulmaları, problem çözme becerilerinin gelişmesi, aileleriyle iletişimde empatik ve ahlâkî soru kullanmaları" şeklinde olduğu tespit edilmiştir.

Araştırmanın bulgu ve sonuçlarına göre, öğretmenlere verilen örnek olay temelli eğitim sonrası öğretmenlerin örnek olayı Hayat Bilgisi derslerinde kullanmalarının niteliğinin belirgin oranda $\operatorname{arttığ~} 1$ ve öğrencilerin bu şekilde işlenen derslerdeki farklılığı hissettikleri ve derslerin bu şekilde işlenmesinden memnun olduklarını ifade ettikleri tespit edilmiştir.

$\mathrm{Bu}$ çalışmadaki bulguları destekler nitelikte olan alanyazındaki benzer çalışmalar incelendiğinde, Gall (2000), Kauffman, Mostert, Trent ve Hallahan (2002)'e göre, öğretmen eğitimi verilen derslerde, geleceğin öğretmeni olacak kişilere gerçek hayat durumları ile problem çözmeye yönelik örnek olay metinlerinin verilmesinin önem taşıdığının ifade edildiği tespit edilmiştir (akt; Lengyel ve Vernon-Dotson, 2010). Darling-Hammond (2006), örnek olay yönteminin teori ve pratik arasında bir köprü niteliğinde olduğunu ifade etmekte ve bu yöntemin süreç içerisinde öğretmen adaylarının yansıtma ve analiz etme becerilerini geliştirdiğini belirtmektedir (akt; Lengyel ve Vernon-Dotson, 2010). Gibson'ın (1998) belirttiğine göre ise, örnek olay temelli öğretim sayesinde öğretmen adayları çeşitli rollere girdikleri için kendilerine güvenleri artmakta, takım çalışması yapabilme ve problem çözme gibi becerileri kazanmaktadırlar (akt; Lengyel ve Vernon-Dotson, 2010).

Ayrıca öğretmen eğitiminde örnek olay yönteminin kullanımı, Levin (1995), Merseth, (1991), Schulman (1987, 1992), Tillman (1995) tarafindan da gerekli görülmektedir (akt; Lengyel ve Vernon-Dotson, 2010). Örnek olay metinleri, birbirinden farklı çeşitli gerçek hayat probleminin ele alındığı güvenli tartışma ortamları sağlamaktadır. Bu problemler çözülmeye çalış1lırken, öğretmen adayları profesyonel kişiler ve yöneticiler eşliğinde farklı fikirler ve çözüm yolları ortaya koymaktadırlar (Lengyel ve Vernon-Dotson, 2010).

\section{Öneriler}

Bütün bu söylenenler 1şığında, Hayat Bilgisi derslerinde örnek olay incelemesi yönteminin kullanımının önemli olduğu görülmektedir. Bu ne- 
denle bundan sonra yapılacak çalışmalara yönelik önerilede bulunulmak istenmiştir:

- Türkiye'de yapılan örnek olay temelli çalışmaların genellikle deneysel desen özelliği taşıması ve nitel çalışmalara çok fazla rastlanılamaması sebebiyle, özellikle bu konuda eylem araştırması niteliğindeki çalışmalara ağırlık verilebilir.

- Öğrencilerin aileleri sürecin dışında tutulmuştur. Ancak özellikle özel okul öğretmenlerinin verdiği bilgiler dâhilinde, velilerin evde çocuklarının sorduğu sorular ve olayları analiz etme şekillerindeki farklılaşmaları fark ettikleri tespit edilmiştir. Bu nedenle ileriki çalışmalarda veliler de sürece dâhil edilerek, öğrencilerin evdeki durumları da analiz edilebilir.

- Yurtdışında örnek olay yöntemiyle ilgili çalışmaların genellikle üniversite öğrencileriyle yapıldığ $\breve{g}_{1}$ tespit edilmiştir. Türkiye'de de özellikle öğretmen adaylarıyla bu çalışmaların yapılıp, ne derece etkili olduğu incelenebilir. Bu araştırmanın pilot uygulaması öğretmen adaylarıyla yapılmıştır ve adayların bu konuda ne kadar istekli oldukları görülmüştür.

- Uluslararası alanyazında geniş bir spektrumda çalışmalar yapılmasına rağmen, ülkemizde sınırlı sayıda konuda örnek olayla ilgili çalışmanın bulunduğu tespit edilmiştir. Bununla ilgili olarak araştırmacılara farklı konularda çalışmalar yapmaları önerilebilir.

- Verilen eğitim sonrasında öğretmenler, bu eğitimi kendi okullarında çalışmakta olan diğer öğretmenlerin de almalarının gerekli olduğunu düşündüklerini ifade etmişlerdir. Bakanlık bu şekilde örnek olay temelli eğitim seminerleri düzenleyerek, öğretmenlerin bu konuda daha fazla bilgi sahibi olmasına yardımcı olabilir.

- Öğretmenlerin Hayat Bilgisi ve Sosyal Bilgiler derslerinde kullanmak üzere aldıkları örnek olay temelli eğitimi, diğer derslerde de kullanmaları yöntemin diğer derslere transfer edilebilmesi bakımından önem taşıyan bir unsur olabilir.

\section{Kaynakça}

Aydın, M. Z. (2011). Okulda ahlak ĕgitimi ve ahlak öğretiminde örnek olay incelemesi yöntemi. Ankara: Nobel Yayınc1lı.

Badger, J. (2010). Classification and framing in the case method: Discussion leaders' questions. Journal of Further and Higher Education, 34(4), 
503-518.

Beckisheva, T., Gasparyan, G. A. ve Kovalenko, N. A. (2015). Case study as an active method of teaching business English. Procedia Social and Behavioral Sciences, 166, 292-295.

Bolger, N., Davis, A. ve Rafaeli, E. (2003). Diary methods: Capturing life as it is lived. Annual Review of Psychology, 54, 579-616.

Farahani, L. A. ve Heidari, T. (2013). Effects of the case-based instruction method on the experience of learning. Journal of Biological Education, $48(1), 40-45$.

Kabapınar, Y. ve Baysal, Z. N. (2004). İlköğretimde hayat bilgisi ve sosyal bilgiler öğretimine yaşamın kendisini taşımak: gazete haberinin kullanıldığ1 bir öğretimin tasarlanması ve değerlendirilmesi, Kuram ve Uygulamada Ĕ̈itim Yönetimi, 10(39), 384-419.

Kabapınar, Y. (2009). Illkögrretimde hayat bilgisi ve sosyal bilgiler ögretimi. Ankara: Maya Akademi.

Kabapınar, Y. (2012). Kuramdan uygulamaya hayat bilgisi ve sosyal bilgiler ögretimi. Ankara: Pegem Akademi Yayıncılık.

Lengyel, L. ve Vernon-Dotson, L. (2010). Preparing special education teacher candidates: Extending case method to pratice. Teacher Education and Special Education, 33(3), 248-256.

McNiff, J. ve Whitehead, J. (2002). Action research: Principles and practi$c e$. London and Newyork: Taylor \& Francis Group.

Milli Eğitim Bakanlığı [MEB], (2009). İlköğretim hayat bilgisi dersi 1-3. sinıflar ögretim programı. Ankara: Milli Eğitim Basımevi.

Morris, R. V. (2001). Drama and authentic assessment in a social studies classroom. The Social Studies, 92(1), 41-44.

Özkan, Ö. (2010). Örnek olay yönteminin hayat bilgisi dersi ögrrenme ortamlarında kullanımının etkililiği. Yayınlanmamış yüksek lisans tezi, Marmara Üniversitesi Eğitim Bilimleri Enstitüsü.

Ütkür, N. (2016). Öğretmenlerin kullandıkları yöntem ve teknik farklılıkları: Hayat bilgisi dersi örneği. Abant İzzet Baysal Üniversitesi Ĕgitim Fakültesi Dergisi, 16(USBES Özel Say1 II), 1631-1651. 
Ütkür, N., Kabapınar, Y. ve Önder, A. (2016). Örnek olay yönteminin hayat bilgisi derslerinde kullanımına yönelik bir eylem araştırması. Hasan Ali Yücel Eğitim Fakültesi Dergisi, 13(2), 41-58.

Patton, M. Q. (2014). Nitel araştırma ve değerlendirme yöntemleri. M. Bütün ve S. B. Demir, (Çev. Ed.), Ankara: Pegem Akademi Yayıncılık. (Orijinal çalışma basım tarihi 2014.)

Rosler, B. (2008). Process drama in one fifth-grade social studies class. The Social Studies, 99(6), 265-272.

Schroeder, C., Scott, T. P., Tolson, H., Huang, T. ve Lee, V. (2007). A meta-analysis of national research: Effects of teaching strategies on student achievement in science in United States. Journal of Research in Science Teaching, 44(10), 1436-1460.

Yıldırım, A. ve Şimşek, H. (2011). Sosyal bilimlerde nitel araştırma yöntemleri. Ankara: Seçkin Yayınevi.

Yurdugül, H. (2005, Eylül). Ölçek geliştirme çalışmalarında kapsam geçerliği için kapsam geçerlik indekslerinin kullanılması. XIV. Ulusal Eğitim Bilimleri Kongresi içinde. Pamukkale Üniversitesi’nde yapılan kongre, Denizli. 